\title{
PENGARUH LATIHAN AEROBIK TERHADAP FORCED VITAL CAPACITY (FVC)PRIA DEWASA DENGANOVERWEIGHT
}

\author{
${ }^{1}$ Ester Florencia Sagay \\ ${ }^{2}$ Hedison Polii \\ ${ }^{2}$ Herlina I. S. Wungouw
}

\author{
${ }^{1}$ Kandidat Skripsi Fakultas Kedokteran Universitas Sam Ratulangi Manado \\ ${ }^{2}$ Bagian Fisiologi Fakultas Kedokteran Universitas Sam Ratulangi Manado \\ Email: ester.luvjesus@gmail.com
}

\begin{abstract}
Changes to respiratory function due to regular aerobic exercise will affect the value of pulmonary function, especially in Forced Vital Capacity (FVC). This research aimed to determine the effect of aerobic exercise on FVC overweight male students of Unsrat Medical Faculty. This research is analytic with design experimental, one group pre and post test design. The sampling technique used is non-purposive sampling technique. The research sample was taken from the students of the Faculty of Medicine 2009, Univercity of Sam Ratulangi who fulfill the inclusion criteria. Some 32 students were selected as research subjects. After giving informed consent, FVC measurement was done with the spirometer. After it was measured, they were given treatmen in the form aerobic exercise using a stationary bike for three weeks with frequency of exercise three times a week and exercise intensity for 30 minutes. We measured again FVC values after the exercise three times program. Normality test data showed significance for FVC value before treatment by 0.752 , and after treatment by 0.912 . Comparison of the average value before and after exercise were tested by using a paired test. Significant value for FVC is $\mathrm{P}=0.084$, means there is no significant difference between FVC values before and after exercise $(\mathrm{P}>0.05)$. The mean FVC was 3.88 before treatment and after treatment the mean value was 4.00 , an increase in the average value of 0.11. Conclusion: Aerobic Exercise on a regular basis using a stationary bike on the overweight male student can improve lung function in particular the mean FVC but there was no significant difference from the mean value.
\end{abstract}

Keywords: FVC, Aerobic Exercise, Overweight.

\begin{abstract}
Abstrak: Perubahan fungsi pernapasan karena latihan aerobik secara teratur akan mempengaruhi nilai fungsi paru khususnya Forced Vital Capacity (FVC). Penelitian ini untuk mengetahui pengaruh latihan aerobik terhadap FVC mahasiswa pria Fakultas Kedokteran Unsrat dengan berat badan lebih.Penelitian ini bersifat analitik dengan rancangan eksperimental one grup pre and post test design. Pengambilan sampel dilakukan dengan teknik non purposive sampling. Sampel penelitian diambil dari Mahasiswa Fakultas Kedokteran Universitas Sam Ratulangi Angkatan 2009.Sejumlah 32 orang mahasiswa terpilih sebagai subjek penelitian dan dilakukan pengukuran FVC dengan Spirometer.Setelah itu diberikan perlakuan berupa latihan aerobik menggunakan sepeda statis selama tiga minggu dengan frekuensi latihan tiga kali seminggu dan intensitas latihan selama 30 menit.Selanjutnya dilakukan pengukuran kembali nilai $F V C$ sesudah program latihan.Uji normalitas data menunjukkan nilai signifikansi untuk FVC sebelum perlakuan sebesar 0.752 , dan sesudah perlakuan sebesar 0.912. Perbandingan nilai rata rata sebelum dan sesudah latihan diuji dengan menggunakan uji t berpasangan.Nilai signifikan untuk $F V C$ adalah $\mathrm{P}=$ 0.084 , berarti tidak terdapat perbedaan yang bermakna antara nilai $F V C$ sebelum dan sesudah latihan $(\mathrm{P}>0.05)$.Nilai rerata $F V C$ sebelum pelakuan adalah 3,88 dan nilai rerata sesudah perlakuan adalah 4,00, terjadi penigkatan nilai rerata sebesar 0,11. Simpulan: Latihan
\end{abstract}


Aerobik menggunakan sepeda statis secara teratur dapat meningkatkan nilai rerata fungsi paru khususnya $F V C$ tetapi tidak terdapat perbedaan yang bermakna dari nilai rerata tersebut.

Kata Kunci: FVC, Latihan Aerobik, Berat Badan Lebih (Overweight).

WHO mengemukakan bahwa kegemukan merupakan faktor resiko utama untuk sejumlah penyakit kronis diantaranya penyakit jantung, paru dan kanker. Kegemukan yang sebelumnya menjadi masalah di negara-negara maju sekarang mulai menjadi masalah besar di Negara berkembang termasuk di Indonesia. WHO mendefinisikan orang dewasa yang memiliki BMI lebih dari 23 tergolong kelebihan berat badan (overweight).Data WHO tahun 2010 sebanyak $2.1 \%$ atau sekitar 40 juta penduduk Indonesia yang berusia lebih dari 15 tahun mengalami kegemukan dan $0.2 \%$ diantaranya adalah laki-laki, berbeda dengan tahun 2005 penduduk dengan berat badan lebih yang hanya $1.4 \%$. Bahkan diprediksi WHO pada tahun 2015 akan meningkat menjadi 2.9\%. ${ }^{1}$

Kelebihan berat badan merupakan suatu kelainan kompleks pengaturan nafsu makan dan metabolisme energi yang dikendalikan oleh beberapa faktor biologik yang spesifik. Faktor genetik diketahui sangat berpengaruh bagi perkembangannya, secara fisiologis, berat badan lebih diartikan sebagai suatu keadaan dengan akumulasi lemak yang tidak normal atau kelebihan dijaringan adipose sehingga dapat mengganggu kesehatan. ${ }^{2}$ Penelitian Framingham menunjukkan bahwa 20\% kegemukan merupakan suatu resiko kesehatan, meskipun kelebihan makan merupakan penyebab kegemukan yang umum kurangnya latihan atau aktifitas fisik juga menjadi faktor yang berpengaruh. Kenaikan sedikit berat badan yang sering terjadi pada umur pertengahan lebih disebabkan oleh aktifitas fisik yang kurang. ${ }^{3}$

Latihan fisik atau exercise merupakan subkelompok aktivitas fisik berupa gerakan tubuh yang terencana, terstruktur dan repetitive (berulang) untuk mencapai tujuan tertentu. ${ }^{4}$ Latihan ini bisa dilakukan dengan menggunakan alat seperti treadmill dan sepeda statis.Sepeda statis dan treadmill merupakan modalitas lati-han dinamik yang paling umum dipakai. Penggunaan sepeda statis lebih murah serta hanya membutuhkan ruangan yang lebih sempit dan tidak terlalu bising. ${ }^{5}$ Penggunaan sepeda statis terbukti memiliki beban kerja yang lebih ringan dibandingkan treadmill pada orang dengan berat badan lebih yang tidak perlu menopang berat tubuhnya sendiri, ${ }^{6}$ selain itu juga karena lebih sedikit gerakkan tubuh bagian atas yang bisa dilakukan dapat memungkinkan kita untuk merekam tanda-tanda vital ataupun mengumpulkan sampel darah selama latihan berlangsung sehingga lebih mudah untuk digunakan dalam penelitian. ${ }^{7}$

Selain latihan fisik, berat badan lebih seperti obesitas dan overweight juga memiliki pengaruh terhadap fungsi paru, pada penelitian case control di Swedia lebih dari 2000 subjek penelitian menunjukkan bahwa penurunan berat badan memiliki efek terhadap penurunan gejala penyakit pernapasan seperti dyspnea. ${ }^{8}$ Abnormalitas fungsi paru yang paling sering dijumpai pada obesitas adalah penurunan expiratory reserve volume (ERV) dan Forced Vital Capacity (FVC). Sebuah penelitian pada 29 pasien dengan berat badan lebih yang mengalami penurunan berat badan terjadi peningkatan fungsi paru expiratory reserve volume (ERV) dan Forced Vital Capacity $(F V C) .{ }^{9}$ Penelitian lain di Iran juga membuktikan bahwa latihan aerobik selama beberapa minggu secara rutin dapat meningkatkan fungsi paru seperti Forced Vital Capacity (FVC) dan FEV1 pada siswa overweight dan obesitas karena terjadi peningkatan kinerja dari otot pernapasan dan ventilasi. ${ }^{10}$

Penelitian tentang pengaruh latihan terhadap fungsi paru telah banyak dilakukan baik di luar negeri ataupun di Indonesia, tetapi masih jarang diteliti pada orang dengan kelebihan berat badan (overweight) apalagi dengan menggunakan alat 
khususnya sepeda statisdengan frekuensi latihan cukup yang lama. Penelitian ini dilakukan untuk mengetahui pengaruh latihan aerobik dengan menggunakan sepeda statis terhadap Forced Vital Capacity (FVC) pada mahasiswa pria Fakultas Kedokteran Umum Unsrat dengan berat badan lebih.

\section{METODE}

Desain pada penelitian ini adalah eksperimental one group pre and post test design. Penelitian dilakukan di tempat Pusat Kebugaran Hardcore Manado Sulawesi Utara dilakukan sepanjang bulan Desember 2012 Populasi dalam penelitian ini adalah seluruh Mahasiswa Fakultas Kedokteran Unsrat Angkatan 2009 yang berjumlah 350 orang. Teknik pengambilan sampel adalah non random sampling (purposive sampling). Sampel berjumlah 32 orang. Kategori drop out yakni berhenti melaksanaan Program kegiatan selama tiga minggu. Latihan Sepeda Statis pada penelitian ini yakni latihan yang dilakukan pada sebuah alat berupa sebuah sepeda bertenaga listrik di pusat kebugaran, dengan tingkat resistensi pada kayuhan yang dapat diubahubah.Forced Vital Capacity (FVC) yaitu volume udara maksimum yang dapat dihembuskan secara paksa dalam satu kali bernapas dari inspirasi maksimal ke ekspirasi maksimal, skala pengukurannya adalah menggunakan volume (L).

Alat dan bahan penelitian berupa sepeda statis merek Rhyno, spirometer merek Microlab, timbangan merek Omron, meteran untuk mengukur tinggi badan dan mouthpiece. Penelitian ini dilakukan dengan penjelasan kepada subjek selanjutnya dilakukan pengukuran FVC menggunakan spirometer kemudian diberikan perlakuan latihan sepeda statisselama 30 menit dilakukan sebanyak tiga kali seminggu selama tiga minggu dan dilakukan pengukuran FVC kembali.

\section{HASIL}

Sampel diambil dari sebagian populasi yang telah memenuhi kriteria inklusi.
Pemilihan sampel berdasarkan keinginan peneliti dan diperoleh sebanyak 32 subjek. Dua subjek drop out, dikarenakan tidak mengikuti seluruh penelitian, sehingga sampel penelitian menjadi 28 subjek.

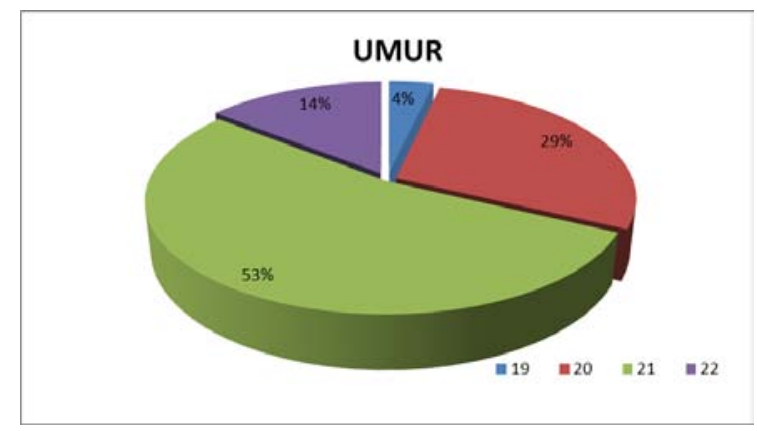

Gambar 1. Grafik distribusi frekuensi umur.

\section{Distribusi subjek berdasarkan umur}

Beberapa analisis data hasil penelitian yang akan dijelaskan dalam penelitian ini meliputi distribusi frekuensi berdasarkan umur, pada Gambar 1 di bawah menunjukkan bahwa dari 28 subjek yang semuanya adalah Mahasiswa Fakultas Kedokteran Unsrat angkatan 2009 berdasarkan umur subjek yaitu yang berumur 19 tahun berjumlah satu orang subjek, 20 tahun berjumlah delapan orang subjek, umur 21 tahun berjumlah 15 orang subjek, umur 22 tahun berjumlah empat orang subjek. Jenis kelamin subjek pada penelitian ini adalah semuanya $100 \%$ berjenis kelamin laki-laki.

\section{Distribusi subjek berdasarkan tinggi badan, berat badan dan IMT}

Tabel 1 dibawah ini menunjukkan bahwa tinggi badan minimum dari 28 responden yaitu $163 \mathrm{~cm}$ dan maksimum yaitu $183 \mathrm{~cm}$ dengan rerata tinggi badan subjek $171.29 \pm 4$ sedangkan untuk berat badan minimum yaitu $65 \mathrm{~kg}$ dan maksimum yaitu $112 \mathrm{~kg}$ dengan berat badan rerata $77.71 \pm 10.128$. IMT responden adalah berkisar antara 23.29 29.21 sesuai dengan klasifikasi WHO untuk orang Asia masuk dalam kategori Overweight rerata IMT $26.477 \pm 3.298$. 
Tabel 1. Rerata dan kisaran tinggi badan dan berat badan.

\begin{tabular}{lll}
\hline & Nilai kisaran & Rerata \pm SD \\
\hline TB & $163-183$ & $171.29 \pm 4.233$ \\
BB & $65-112$ & $77.71 \pm 10.128$ \\
IMT & $23.29-39.21$ & $26.477 \pm 3.298$ \\
\hline
\end{tabular}

\section{Nilai Forced Vital Capacity (FVC) sebelum dan sesudah latihan aerobik}

Berdasarkan hasil uji statistik menunjukkan nilai rerata FVC sebelum dan sesudah latihan yaitu $3.8818 \mathrm{~L}$ menjadi 4.0000 L. Data hasil uji statistik pengukuran rerata sebelum dan sesudah latihan ergocycle dapat dilihat dalam tabel dibawah ini:

Tabel 2. Rerata nilai FVC sebelum dan sesudah latihan.

\begin{tabular}{cc}
\hline $\begin{array}{c}\text { Forced Vital } \\
\text { Capacity (FVC) }\end{array}$ & Rerata (Liter) \\
\hline Sebelum & 3.8818 \\
Sesudah & 4.0000 \\
\hline
\end{tabular}

Tabel diatas menunjukkan terdapat perbedaan nilai rerata FVC sebelum dan sesudah latihan. Data pertama diambil sebelum melakukan latihan ergocycle dan data selanjutnya yaitu setelah melakukan latihan tersebut selama kurun waktu tiga minggu.

\section{Pengaruh Latihan Aerobik terhadap Forced Vital Capacity (FVC)}

Berdasarkan hasil uji normalitas data dalam penelitian ini dengan statistik non parametrik menggunakan kolmogorovsmirnov. Ketentuan yang harus dipenuhi untuk menguji normalitas ini yaitu jika nilai signifikansi $>0.05$ berarti normal, dan jika nilai signifikansi $<0.05$ berarti tidak normal. Dari perhitungan diperoleh hasil:

Tabel. 3. Uji normalitas data.

\begin{tabular}{lcc}
\hline Variabel & Signifikansi & Ket \\
\hline FVC Sebelum & $0.752>0.05$ & Normal \\
FVC Sesudah & $0.912>0.05$ & Normal \\
\hline
\end{tabular}

Berdasarkan Tabel 3 dapat dilihat data hasil FVC mahasiswa sebelum dan sesudah melakukan latihan sepeda statis memiliki nilai signifikansi sehingga kita dapat menyimpulkan bahwa semua kelompok data tersebut berdistribusi normal. Dengan demikian dapat dilanjutkan analisis data dengan menggunakan statistik parametrik. Uji statistik yang digunakan adalah uji t berpasangan yaitu untuk melihat apakah ada pengaruh latihan sepeda statis terhadap nilai FVC seseorang. Uji ini dimaksudkan untuk menguji perbedaan rata-rata sebelum dan sesudah latihan. Hasilnya terdapat peningkatan rerata sebelum dan sesudah latihan (Gambar. 2) yaitu sebesar 0.1182 Liter tetapi tidak terdapat perbedaan yang signifikan atau bermakna sebelum dan sesudah latihan sepeda statis $(\mathrm{P}>0.05)$.

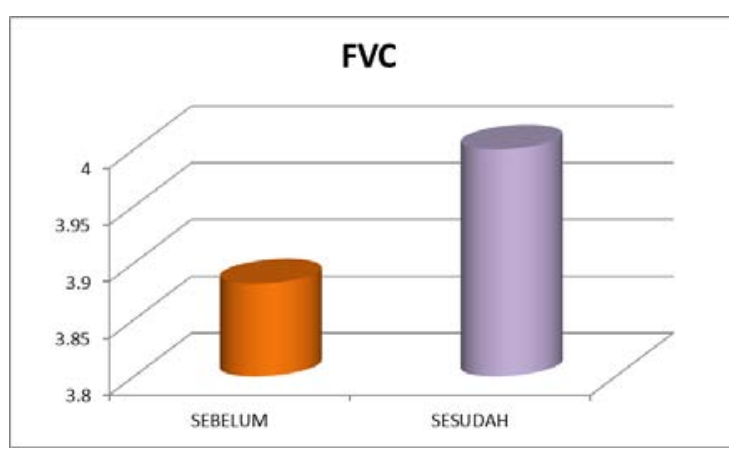

Gambar 2. Nilai rerata FVC sebelum dan sesudah perlakuan.

\section{BAHASAN}

Penelitian dilakukan terhadap subjek yang semuanya adalah mahasiswa pria dengan kisaran umur 19 - 22 tahun masuk dalam kriteria inklusi pada penelitian ini karena pada usia ini biasanya berada pada stamina puncak. IMT berkisar antara 23.2939.21 sesuai dengan klasifikasi WHO untuk orang Asia masuk dalam kategori Overweight yaitu kelebihan berat badan. Data tersebut sesuai dengan yang menjadi subjek pada penelitian yaitu pada orangorang yang memiliki berat badan lebih, berdasarkan penelitian di Australia, orang dengan kelebihan berat badan meningkatkan risiko gejala pernapasan, seperti sesak 
napas, terutama selama berolahraga, bahkan jika mereka tidak memiliki penyakit pernafasan yang jelas. Selain itu, kelebihan berat badan juga berkontribusi terhadap disfungsi saluran napas yang dapat menimbulkan atau bahkan memperburuk asma. ${ }^{11}$

\section{Pengaruh Latihan Aerobik terhadap Forced Vital Capacity (FVC)}

Penelitian dilakukan selama tiga minggu dengan frekuensi latihan tiga kali seminggu dengan tempo 30 menit yang diharapkan dapat memberikan efek terhadap perubahan fungsi paru khususnya FVC.Pemeriksaan dilakukan sebelum dan sesudah melakukan latihan aerobik berupa latihan sepeda statis. Data statistik menunjukkan perubahan rata-rata nilai FVC sebelum dan sesudah latihan menggunakan sepeda statis yaitu 3.8818 menjadi 4.0000 , terjadi peningkatan nilai rata-rata sebelum dan sesudah latihan sebesar 0,11 , berdasarkan penelitian Khalili MA et al, bahwa latihan aerobik dapat meningkatkan fungsi paru-paru pada anak-anak dengan keterbatasan intelektual, ${ }^{12}$ selain itu penelitian lain juga membuktikan bahwa adanya latihan fisik dapat mempengaruhi kapasitas paru- paru seperti FVC serta daya difusi lebih tinggi. ${ }^{13}$ Latihan aerobik juga dapat meningkatkan fungsi paru berupa peningkatan kinerja otot-otot pernapasan dan penurunan komposisi lemak di dinding dada serta peningkatan sirkulasi paruparu, ${ }^{10}$ penelitian lain juga menunjukkan bahwa perenang yang terlatih memiliki volume statis paru yang besar dan terjadi peningkatan fungsi paru dibandingkan kelompok kontrol, ${ }^{14}$ hal ini mendukung apa yang dikemukakan Guyton dan Hall (2007), yang menyatakan bahwa pada kerja fisik yang berat kapasitas difusi $\mathrm{O} 2$ dapat meningkat sampai menjadi $65 \mathrm{~mL} /$ menit/ mmHg (tiga kali). Penelitian yang dilakukan Ferdowsi et al FVC dipengaruhi oleh otot-otot tulang rusuk. Oleh karena itu juga peningkatan kekuatan otot pernapasan, penurunan komposisi lemak pada dinding dada dan peningkatan daya tahan tubuh pada gilirannya akan meningkatkan $F V C{ }^{15}$
Setelah dilakukan uji -t berpasangan disimpulkan bahwa tidak terjadi perubahan signifikan yang secara statistik bermakna sebelum dan sesudah latihan sepeda statis $(P>0.05)$. Hal ini tidak sesuai dengan penelitian yang dilakukan sebelumnya oleh National Research Institute of Tuberculosis and Lung Disease yang dilakukan selama delapan minggu, ${ }^{10}$ yaitu bahwa latihan aerobik seperti halnya latihan sepeda statis memiliki pengaruh yang baik untuk peningkatan fungsi pernapasan dilihat dari peningkatan nilai FVC pada semua subjek penelitian, selain itu hasil ini juga tidak mendukung penelitian dari Boutellier et al (1992), yang mendapatkan perubahan dalam kapasitas fungsi paru selama latihan yang meningkatkan kerja otot paru, sehingga paru dapat menggunakan udara yang lebih banyak. Peningkatan dalam ventilasi semenit dan penurunan dalam frekuensi pernapasan pada kelompok terlatih menunjukkan peningkatan kekuatan pernapasan. Peningkatan kekuatan otot pernapasan memungkinkan subyek tersebut melakukan pekerjaan yang lebih besar (menggunakan udara yang lebih banyak) sementara bernapas dalam waktu yang lebih sedikit, ${ }^{16}$ mungkin hal ini tidak terjadi dikarenakan latihan yang dilakukan hanya selama tiga minggu sehingga sebagian dari subjek yang nilai FVC mengalami penurunan \& belum terjadi adaptasi fisiologis, adaptasi terhadap sistem pernapasan yang terjadi disini adalah adaptasi dari latihan berupa perubahan fungsional dari kekuatan otot pernapasan bukan pada struktur pernapasan itu sendiri. ${ }^{17}$

\section{SIMPULAN}

Tidak ada pengaruh yang bermakna Latihan Aerobik menggunakan sepeda statis terhadap nilai Forced Vital Capacity ( $F V C$ ).Latihan Aerobik menggunakan sepeda statis dapat meningkatkan nilai ratarata $F V C$ sebelum dan sesudah latihan tetapi belum bermakna secara statistik.

\section{DAFTAR PUSTAKA}

1. www.WHO.int/ WHO Global infobase. 2011. diakses November 2012. 
2. Sudoyo AW, Setiyohadi B, Alwi I, Simadibrata K, Setiati S. Buku Ajar Ilmu Penyakit Dalam Edisi 5. Penerbit Internal Publishing. 2009.

3. Isselbacher KJ, Braunwald E, Wilson JD, Martin JB, Fauci AS, Kasper DL Harrison's principles of internal medicine Volume 1. Harrison Prinsip -prinsip Ilmu Penyakit Dalam Asdie AH, editor. Penerbit EGC Jakarta, hal 498.2002

4. Public Health Nutrition edited Gibney MJ, Barrie M, Margetts, Kearney JM, Arab L. Oxford 2005. Gizi Kesehatan Masyarakat editor Widyastuti P, Hardiyanti EA. Jakarta.hal 103. 2008.

5. Rai A, Tsiang H. Tingkatkan Fitness Iq Anda: Rahasia Tuntas Bakar Lemak dan Gaya Hidup Sehat. Penerbit : Libri. Jakarta. 2009.

6. Venkata Ramana $Y$ Skmsrsabn. Comparison of training loads and physiological responses in athletes: consideration of body weight implications. [3], 134-139. 2012. JEPonline diunduh Oktober 2012.

7. Shephard RJ, Allen C, Benade AJ, Davies CT, Di Prampero PE, Hedman $\mathbf{R}$, et al. Standardization of submaximal exercise tests. Bull World Health Organ 1968;38(5):765-75. Diunduh Oktober 2012.

8. Karason $K$, Lindroos AK, Stenlof $K$, Sjostrom L. Relief of Cardiorespiratory symptoms and Increased Physycal Activity after surgically Induced Weight Loss.2002. diunduh November 2012.

9. Arruda M, Xavier F, Cenevival R, Filho JT, Kumar A Sankarankutt. Pulmonary function and quality of life in patients with morbid obesity six months after bariatric surgery. 2010.Diunduh November 2012.
10. Azad A, Gharakhanlou R, Niknam A, Ghanbari A. Effects of Aerobic Exercise on Lung Function in Overweight and Obese Students. Tanaffos. 2011. Diunduh Desember 2012.

11. Piper AJ, Grunstein RR. Big breathing: the complex interaction of obesity, hypoventilation, weightloss, and respiratory function. University of Sydney. Sydney. 2009. Diunduh Desember 2012.

12. Khalili. MA, Elkins MR .Aerobic exercise improves lung function in children with intellectual disability: a randomised trial. Australia. 2009. diunduh Januari 2013.

13. Jordan A G, Witt JD, McKenzie DC, Road DJ , William A. Respiratory mechanics during exercise in endurancetrained men and women. J Physiol. 2007. Januari 2013.

14. Cordain L, Stager J. Pulmonary structure and function in swimmers. Sports Med. 1988. Diunduh Jauari 2013.

15. Ferdowsi, Hassan $M$, Saiiari, Abdulamir, Valizadeh, Rohollah, Gholamie, Alinaghi. The effect of eight week aerobic exercise on airway trachea indexes (FEV1, FVC, FEV1.FVC \& FEF25-75) and vo2max level in overweighed male students of Ahvaz Payam Noor University.2011. Diunduh Desember 2012.

16. Boutellier U, Buchel R, Kundert A, and Spengler $\mathbf{C}$. The respiratory system as an exercise limiting factor in normal trained subjects. Eur. J. Apply. Physiol. Occup. Physiol. 1992. Diunduh Januari 2013.

17. McKenzie DC.Respiratory physiology: adaptations to high-level exercise.The University of British Columbia, Division of Sports Medicine.2011. Diunduh Januari 2013. 